\title{
ANALISIS DAN MITIGASI RISIKO MENGGUNAKAN HOUSE OF RISK DAN FUZZY LOGIC PADA RANTAI PASOK PT. PETRONIKA
}

\author{
Kiki Irnanda Safitri ${ }^{1}$, Said Salim Dahda ${ }^{2}$, Dzakiyah Widyaningrum ${ }^{3}$ \\ ${ }^{1)}$ Mahasiswi Teknik Industri Universitas Muhammadiyah Gresik, ${ }^{2,3)}$ Dosen Universitas \\ Muhammadiyah Gresik \\ Program Studi Teknik Industri, Fakultas Teknik, Universitas Muhammadiyah Gresik \\ J1. Sumatera $101 \mathrm{GKB}$, Gresik 61121, Indonesia \\ E-mail : kinandasftr@gmail.com
}

\begin{abstract}
ABSTRAK
Pada sebuah supply chain terdapat risiko - risiko yang dapat muncul dan mempengaruhi aktivitas supply chain sehingga aktivitas supply chain tidak dapat berjalan dengan baik. Hal tersebut juga dialami oleh PT. Petronika dimana terdapat gangguan terhadap aktivitas supply chain perusahaan. Saat ini PT. Petronika belum mengidentifikasi dan memitigasi risiko yang terstruktur, terutama dalam fungsi supply chain. Maka dari itu diperlukan adanya manajemen risiko rantai pasok atau biasa disebut SCRM. House of risk merupakan metode yang cocok untuk mengidentifikasi risiko disepanjang rantai pasok. Pengolahan HOR fase 1 bertujuan untuk mendapatkan urutan prioritas sumber risiko yang akan diberi penanganan, dimana akan menjadi input pada HOR fase 2. Hasil pengolahan HOR fase 2 adalah prioritas aksi mitigasi risiko. Dalam prakteknya mengenai penanganan risiko beberapa peneliti menggunakan pendekatan HOR. Namun pada saat proses pengambilan data kuesioner severity dan occurrence peneliti menggunakan logika fuzzy karena logika fuzzy memiliki toleransi terhadap data-data yang tidak tepat. Dari hasil penelitian terdapat 22 risk event dan 52 risk agent yang teridentifikasi. Peneliti mengusulkan 8 strategi mitigasi untuk dilakukan penanganan terhadap 2 prioritas risk agent. Dari hasil penelitian ini diharapkan bisa menjadi rekomendasi perbaikan pada kegiatan supply chain PT. Petronika.
\end{abstract}

Kata kunci : Supply Chain Risk Management (SCRM), House of Risk (HOR), Fuzzy Logic.

\section{PENDAHULUAN}

Pada sebuah supply chain terdapat risiko risiko yang dapat muncul dan mempengaruhi aktivitas supply chain sehingga aktivitas supply chain tidak dapat berjalan dengan baik. Gangguan atau risiko dalam supply chain berdampak negatif dalam jangka panjang terhadap perusahaan dan banyak perusahaan tidak mampu pulih secara cepat dari dampak negatif tersebut (Tampubolon dkk., 2013). Oleh karena itu, perlu pengendalian risiko supply chain untuk menghindari akibat berkelanjutan yang dapat terjadi pada setiap titik dalam jaringan pasokan (Winanto \& Santoso, 2017) dengan cara memperkecil risiko - risiko yang muncul dengan dilakukan identifikasi risiko pada supply chain sehingga dapat digunakan untuk merancang strategi penanganan risiko untuk memperkecil tingkat risiko yang muncul. Dalam melakukan identifikasi risiko yang muncul pada supply chain diperlukan manajemen risiko yang baik dalam supply chain (Bahauddin dkk., 2015).

PT. Petronika merupakan perusahaan yang menghasilkan produk berupa liquid atau cairan yang diberi nama Dioctyl Phthalate (DOP) dan
Diisononyl Phthalate (DINP). Keberadaan perusahaan yang memproduksi DOP dan DINP ini dimaksudkan untuk memenuhi kebutuhan industri plastik atau PVC (Sumber : PT. Petronika, 2018). Kebutuhan plastik atau PVC dari tahun ke tahun terus meningkat, akibat dari meningkatnya kebutuhan DOP dan DINP dapat mengakibatkan aktivitas pada kegiatan supply chain pada perusahaan ini semakin kompleks dengan melibatkan banyak pihak yang dapat menimbulkan adanya ketidakpastian pada aktivitas tersebut. Pada perusahaan ini terdapat risiko - risiko dalam setiap aktivitas supply chain, berikut adalah kegiatan supply chain PT. Petronika yang dapat dilihat pada gambar 1.

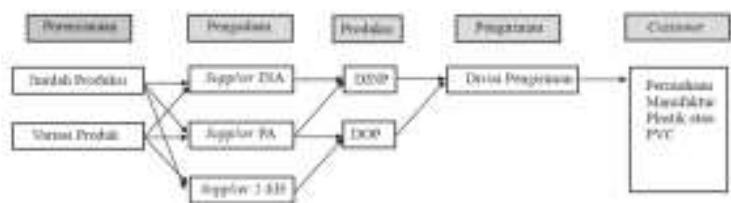

Gambar 1. Alur Supply Chain PT. Petronika

Berdasarkan alur aktivitas supply chain diatas peneliti mengkaji dan mengobservasi keseluruhan proses supply chain telah ditemukan kejadian risiko yang terjadi pada pengadaan bahan baku utama maupun 
penunjang, proses produksi, dan pengiriman produk jadi ke konsumen. Berikut adalah risiko yang terjadi pada proses pengadaan bahan baku dan produksi.

Tabel 1. Risiko Yang Terjadi

\begin{tabular}{|c|c|l|}
\hline \multirow{2}{*}{$\begin{array}{c}\text { Pengadaan } \\
\text { Bahan Baku }\end{array}$} & 1. & $\begin{array}{l}\text { Keterlambatan kedatangan } \\
\text { bahan baku }\end{array}$ \\
\cline { 2 - 3 } & 2. & $\begin{array}{l}\text { Ketersediaan bahan baku } \\
\text { kurang }\end{array}$ \\
\cline { 2 - 3 } & 3. & $\begin{array}{l}\text { Kuantitas bahan baku yang } \\
\text { dikirim supplier tidak } \\
\text { sesuai dengan kontrak }\end{array}$ \\
\hline \multirow{2}{*}{ Proses Produksi } & 2. & $\begin{array}{l}\text { Perubahan } \\
\text { produksi secara mendadak }\end{array}$ \\
\cline { 2 - 4 } & 3. & $\begin{array}{l}\text { Terjadi Downtime saat } \\
\text { proses produksi }\end{array}$ \\
\hline Pengiriman & 1. & $\begin{array}{l}\text { Keterlambatan pengiriman } \\
\text { ke konsumen }\end{array}$ \\
\hline Produk & 2. & $\begin{array}{l}\text { Tidak dapat memenuhi } \\
\text { seluruh } \\
\text { konsumen }\end{array}$ \\
\hline
\end{tabular}

Sumber : PT. Petronika

Karena kejadian yang terjadi diatas mengakibatkan perusahaan tidak dapat mencapai target produksi. Dimana pada bulanbulan tertentu terdapat tidak tercapainya target produksi yang disebabkan adanya downtime. Penyebab utama terjadinya downtime adalah karena keterlambatan kedatangan bahan baku, penyebab lain karena kerusakan alat saat proses produksi, kekurangan bahan baku, dan lain lain (Sumber : Wawancara dengan pihak PT. Petronika).

Selain menyebabkan terjadinya downtime, keterlambatan kedatangan bahan baku juga menyebabkan perubahan rencana produksi secara mendadak. Perubahan rencana produksi secara mendadak juga disebabkan oleh kuantitas bahan baku yang dikirim oleh pihak supplier tidak sesuai dengan yang telah disepakati. Karena kejadian tersebut membuat proses produksi tidak dapat mencapai target produksi yang telah direncanakan. Disisi lain juga dapat menyebabkan keterlambatan dalam pengiriman produk ke customer (Sumber : Wawancara dengan pihak PT. Petronika).

Saat ini PT. Petronika belum mengidentifikasi dan memitigasi risiko yang terstruktur, terutama dalam fungsi supply chain.
Maka dari itu diperlukan adanya manajemen risiko rantai pasok atau biasa disebut SCRM. Pemahaman supply chain risk management dapat membantu perusahaan dalam mengelola risiko rantai pasok dan menghadirkan proses manajemen risiko rantai pasok secara menyeluruh pada aktivitas bisnis perusahaan. Dengan demikian, perusahaan dapat mereduksi probabilitas terjadinya risiko dan mengurangi dampak yang ditimbulkan apabila risiko benar - benar terjadi sehingga pengelolaan rantai pasok akan menjadi keunggulan bersaing perusahaan yang berkelanjutan (Sherlywati, 2016).

House of risk merupakan metode yang cocok untuk mengidentifikasi risiko disepanjang rantai pasok. Pada fase 1 diawali dengan pemetaan aktivitas supply chain dan mengidentifikasi risiko kemudian fase ke 2 mengolah matriks sumber risiko dan kejadian risiko untuk mendapatkan urutan prioritas sumber risiko yang akan diberi penanganan, lalu mengolah kembali matriks sumber risiko dengan preventive action dan hasil akhirnya didapatkan urutan prioritas mitigasi risiko sebagai output dari house of risk (Puji, 2018).

Dalam prakteknya mengenai penanganan risiko beberapa peneliti menggunakan pendekatan HOR. Namun pada saat proses pengambilan data kuesioner severity dan occurrence menggunakan fuzzy logic. Fuzzy logic bisa menghasilkan keputusan yang lebih adil (Puji, 2018). Hal ini didukung oleh Kusumadewi (2003) bahwa logika fuzzy memiliki toleransi terhadap data-data yang tidak tepat. Sehingga, pendekatan fuzzy logic diperlukan dalam penelitian ini guna menegaskan nilai keanggotaan yang samar tersebut. Fuzzy logic memodelkan intuisi atau perasaan pada saat tahap fuzzification dan kemudian memasukkannya ke dalam aturan fuzzy yang dibuat berdasarkan pengetahuan. Selain itu, fungsi fuzzy logic juga untuk mengakomodasi sifat dasar manusia yang susah untuk menentukan secara pasti atau ragu - ragu. Dengan pendekatan fuzzy ini diharapkan dapat mempengaruhi hasil yang tepat dan baik berdasarkan apa yang terjadi di lini rantai pasok internal perusahaan menurut pengambil kebijakan. Metode penilaian severity dan occurrence, peneliti menggunakan Fuzzy logic yang dikembangkan oleh Wang et al. (2009).

Berdasarkan uraian diatas, peneliti tertarik untuk meneliti lebih lanjut dalam bentuk skripsi yang berjudul "Analisis dan Mitigasi Risiko 
Menggunakan House of Risk dan Fuzzy Logic Pada Rantai Pasok PT. Petronika". Yang bertujuan untuk mengetahui aktivitas rantai pasok internal PT. Petronika agar dapat mengidentifikai risiko yang ada kemudian bersama dengan pengambil kebijakan memilih aksi mitigasi yang tepat bagi perusahaan. Dari penelitian ini penulis berharap dapat memberi solusi bagi perusahaan dalam melakukan tindakan evaluasi dan mitigasi permasalahan risiko khususnya pada bagian rantai pasok. Sehingga kedepan dapat beroperasi dengan lebih baik.

\section{LANDASAN TEORI}

\section{Supply Chain Risk Management SCRM)} Risqiyah \& Santoso (2017) mengemukakan bahwa manajemen risiko rantai pasok fokus pada bagaimana memahami dan menanggulangi pengaruh berantai ketika risiko kecil atau besar terjadi dalam jaringan rantai pasok. Selanjutnya, memastikan bahwa ketika risiko itu terjadi, pelaku rantai pasok mempunyai kemampuan untuk kembali pada keadaan normal dan melanjutkan bisnisnya. Manajemen rantai pasok terdiri dari identifikasi risiko, analisi risiko, evaluasi risiko dan mitigasi risiko.

$$
\text { Handayani (2014) mengatakan }
$$

bahwasanya SCRM memiliki beberapa jenis, beikut ini jenis - jenis SCRM dan penjelasannya :

1) Operational risk adalah resiko-resiko yang berhubungan dengan operasional organisasi perusahaan.

2) Financial risk adalah resiko yang berdampak pada kinerja perusahaan.

3) Hazard risk adalah Resiko kecelakaan fisik, seperti kejadian Resiko sebagai akibat bencana alam, berbagai kejadian/kerusakan yang menimpa harta perusahaan, dan adanya ancaman pengerusakan.

4) Strategic risk mencakup kejadian Resiko yang berhubungan dengan strategi perusahaan, politik ekonomi, peraturan dan perundangan, pasar bebas, Resiko yang berkaitan dengan reputasi perusahaan, kepemimpinan, dan termasuk perubahan keinginan pelanggan.

\section{House of Risk}

HOR merupakan model terintegrasi dengan menggabungkan dua model yaitu metode Failure Mode and Effect Analysis (FMEA) dan
House of Quality (HOQ). Pada metode HOR ini, FMEA akan digunakan untuk menghitung tingkat resiko yang diperoleh dari perhitungan Risk Potential Number (RPN). Untuk menghitung nilai RPN pada metode FMEA ini ditentukan oleh tiga faktor yaitu probabilitas terjadinya resiko (occurrence), tingkat keparahan dampak (severity) dan probabilitas penemuan resiko (detection) yang masingmasing faktor tersebut memiliki skala penilaian tersendiri. Sedangkan metode HOQ yang diambil dari metode Quality Function Deployment (QFD) akan digunakan untuk membantu dalam proses perancangan strategi sehingga dapat digunakan untuk mengurangi atau mengeliminasi penyebab resiko yang telah teridentifikasi Saepullah (2017).

Terdapat 2 fase yang digunakan dalam melakukan pendekatan HOR yaitu :

1) HOR 1 digunakan untuk menentukan tingkat prioritas agen risiko yang harus diberikan sebagai tidakan pencegahan.

2) HOR 2 adalah prioritas dalam pengambilan tindakan yang dianggap efektif.

\section{Fuzzy Risk Priority Numbers for FMEA}

Telah banyak ditemukan bahwa faktor risiko $\mathrm{S}, \mathrm{O}, \mathrm{D}$ tidak mudah dievaluasi secara tepat. Upaya siginifikan telah dilakukan untuk mengevaluasi mereka dengan cara lingusitik. Tabel 2, Tabel 3, dan Tabel 4 menunjukkan istilah linguistik dan bilangan fuzzy yang digunakan untuk mengevaluasi faktor risiko. Istilah - istilah linguistik ini sangat konsisten dengan yang didefinisikan oleh FMEA tradisional, tetapi mereka diperlakukan sebagai nomor fuzzy trapezoidal dan tringular dalam penelitian ini daripada nilai numerik yang tepat. (Wang et al., 2009).

Tabel 2. Fuzzy Rating untuk Severity

\begin{tabular}{|c|c|c|c|}
\hline Rating & Kode & Severity of Effect & $\begin{array}{c}\text { Fuzzy } \\
\text { Number }\end{array}$ \\
\hline $\begin{array}{l}\text { Hazard } \\
\text { without } \\
\text { warning }\end{array}$ & HWOW & $\begin{array}{l}\text { Tingkat } \\
\text { keparahan } \\
\text { sangat tinggi } \\
\text { tanpa peringatan }\end{array}$ & $(9,10,10)$ \\
\hline $\begin{array}{c}\text { Hazard } \\
\text { with } \\
\text { warning }\end{array}$ & HWW & $\begin{array}{l}\text { Tingkat } \\
\text { keparahan } \\
\text { sangat tinggi } \\
\text { dengan } \\
\text { peringatan }\end{array}$ & $(8,9,10)$ \\
\hline
\end{tabular}




\begin{tabular}{|c|c|c|c|}
\hline Very High & VH & $\begin{array}{l}\text { Sistem tidak } \\
\text { dapat beroperasi } \\
\text { dengan adanya } \\
\text { kegagalan yang } \\
\text { merusak }\end{array}$ & $(7,8,9)$ \\
\hline High & $\mathrm{H}$ & $\begin{array}{l}\text { Sistem tidak } \\
\text { dapat beroperasi } \\
\text { dengan adanya } \\
\text { kerusakan kecil }\end{array}$ & $(6,7,8)$ \\
\hline Moderate & M & $\begin{array}{l}\text { Sistem tidak } \\
\text { dapat beroperasi } \\
\text { dengan adanya } \\
\text { kerusakan kecil }\end{array}$ & $(5,6,7)$ \\
\hline Low & $\mathrm{L}$ & $\begin{array}{l}\text { Sistem tidak } \\
\text { dapat beroperasi } \\
\text { tanpa adanya } \\
\text { kerusakan }\end{array}$ & $(4,5,6)$ \\
\hline Very Low & VL & $\begin{array}{l}\text { Sistem dapat } \\
\text { beroperasi } \\
\text { dengan } \\
\text { penurunan } \\
\text { kinerja secara } \\
\text { signifikan }\end{array}$ & $(3,4,5)$ \\
\hline Minor & MR & $\begin{array}{l}\text { Sistem dapat } \\
\text { beroperasi } \\
\text { dengan beberapa } \\
\text { penurunan } \\
\text { performance }\end{array}$ & $(2,3,4)$ \\
\hline Very Minor & VMR & $\begin{array}{l}\text { Sistem dapat } \\
\text { beroperasi } \\
\text { dengan adanya } \\
\text { gangguan kecil }\end{array}$ & $(1,2,3)$ \\
\hline None & $\mathrm{N}$ & $\begin{array}{ll}\text { Tidak ada } \\
\text { pengaruh }\end{array}$ & $(1,1,2)$ \\
\hline
\end{tabular}

Sumber : Wang et al., 2009

Tabel 3. Fuzzy Rating untuk Occurrence

\begin{tabular}{|c|c|c|c|}
\hline Rating & Kode & $\begin{array}{c}\text { Probability of } \\
\text { Occurance }\end{array}$ & $\begin{array}{c}\text { Fuzzy } \\
\text { Number }\end{array}$ \\
\hline Very High & VH & $\begin{array}{l}\text { Failure tidak } \\
\text { dapat dihindari }\end{array}$ & $\begin{array}{c}(8,9,10, \\
10)\end{array}$ \\
\hline High & $\mathrm{H}$ & $\begin{array}{l}\text { Failure yang } \\
\text { terjadi berulang }\end{array}$ & $(6,7,8,9)$ \\
\hline Moderate & M & $\begin{array}{l}\text { Failure kadang } \\
\text { kali terjadi }\end{array}$ & $(3,4,6,7)$ \\
\hline Low & $\mathrm{L}$ & $\begin{array}{l}\text { Failure relatif } \\
\text { sedikit }\end{array}$ & $(1,2,3,4)$ \\
\hline Remote & $\mathrm{R}$ & $\begin{array}{l}\text { Failure tidak } \\
\text { mungkin terjadi }\end{array}$ & $(1,1,2)$ \\
\hline
\end{tabular}

Sumber : Wang et al., 2009

Tabel 4. Fuzzy Rating untuk Detection

\begin{tabular}{|c|c|c|c|}
\hline Rating & Kode & $\begin{array}{c}\text { Probability of } \\
\text { Detection }\end{array}$ & $\begin{array}{c}\text { Fuzzy } \\
\text { Number }\end{array}$ \\
\hline $\begin{array}{c}\text { Absolute } \\
\text { Uncertainty }\end{array}$ & $\mathrm{AU}$ & $\begin{array}{l}\text { Tidak ada } \\
\text { kesempatan }\end{array}$ & $(9,10,10)$ \\
\hline Very Remote & VR & $\begin{array}{l}\text { Kesempatan } \\
\text { sangat kecil }\end{array}$ & $(8,9,10)$ \\
\hline Remote & $\mathrm{R}$ & $\begin{array}{l}\text { Kesempatan } \\
\text { kecil }\end{array}$ & $(7,8,9)$ \\
\hline Very Low & VL & $\begin{array}{l}\text { Kesempatan } \\
\text { sangat rendah }\end{array}$ & $(6,7,8)$ \\
\hline Low & $\mathrm{L}$ & $\begin{array}{l}\text { Kesempatan } \\
\text { rendah }\end{array}$ & $(5,6,7)$ \\
\hline Moderate & M & $\begin{array}{l}\text { Kesempatan } \\
\text { sedang }\end{array}$ & $(4,5,6)$ \\
\hline $\begin{array}{c}\text { Moderately } \\
\text { High }\end{array}$ & MH & $\begin{array}{l}\text { Kesempatan } \\
\text { cukup tinggi }\end{array}$ & $(3,4,5)$ \\
\hline High & $\mathrm{H}$ & $\begin{array}{l}\text { Kesempatan } \\
\text { tinggi }\end{array}$ & $(2,3,4)$ \\
\hline Very High & VH & $\begin{array}{l}\text { Kesempatan } \\
\text { sangat tinggi }\end{array}$ & $(1,2,3)$ \\
\hline $\begin{array}{l}\text { Almost } \\
\text { Certain }\end{array}$ & $\mathrm{AC}$ & Hampir pasti & $(1,1,2)$ \\
\hline
\end{tabular}

Sumber : Wang et al., 2009

\section{METODOLOGI PENELITIAN}

Penelitian ini dilakukan di PT. Petronika terletak di Jl. Prof. Moch Yamin Sh, Sekarsore, Tlogopojok, Kecamatan Gresik, Kabupaten Gresik, Jawa Timur. Penelitian dilakukan dengan pengamatan lalu brainstorming dengan pihak PT. Petronika mengenai risiko yang mungkin terjadi di perusahaan kemudian dilakukan identiikasi. Data-data yang dikumpulkan sebagai bahan penelitian adalah data kejadian risiko dan agen risiko beserta nilai severity dan occurance nya. Nilai severity dan occurance menggunakan nilai fuzzy dan nilai tersebut setiap risikonya didapat dengan memberikan kuisioner kepada pihak yang telah dipilih oleh perusahaan. Berikut ini flowchart dari penelitian ini. 


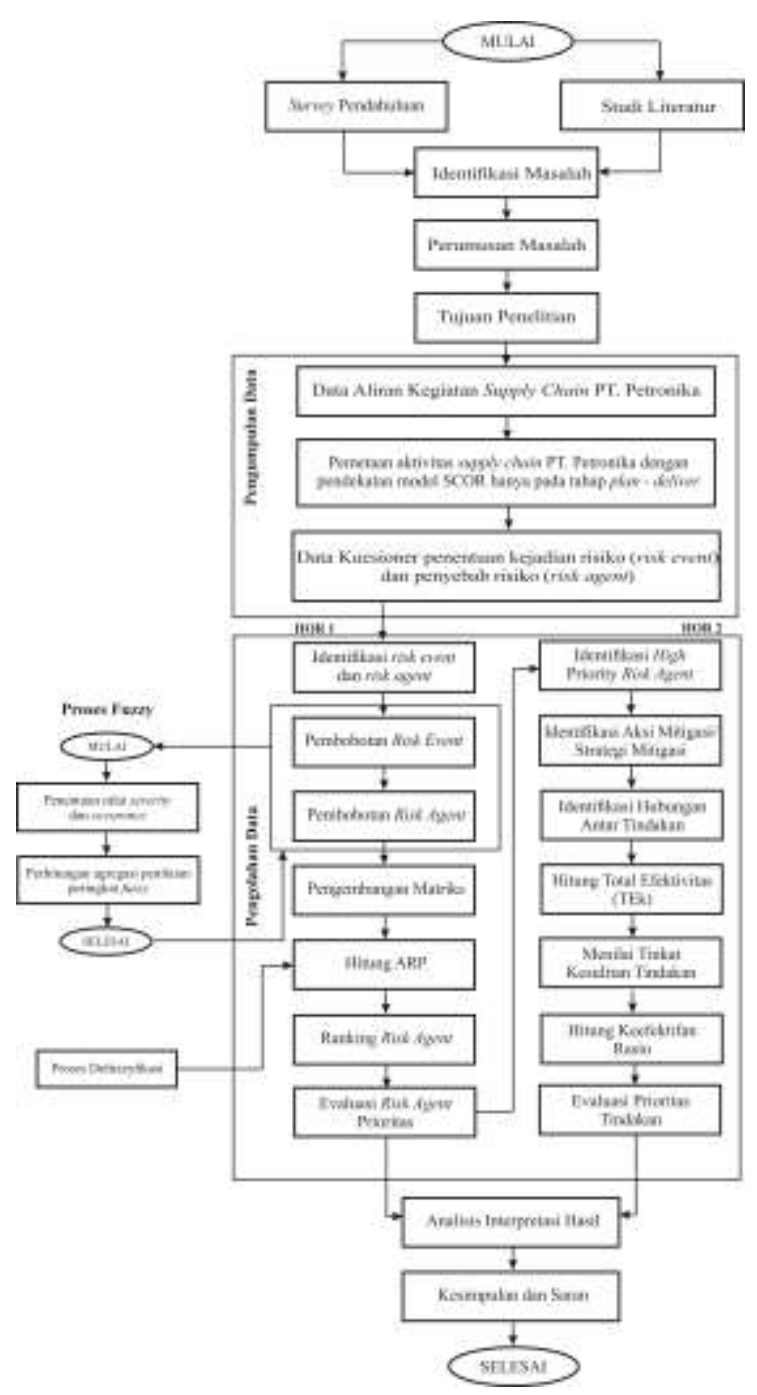

Gambar 2. Kerangka Penelitian

\section{HASIL \& PEMBAHASAN}

\section{Pemetaan Aktivitas Supply Chain}

Pemetaan aktivitas rantai pasok di PT. Petronika dilakukan dengan menggunakan pendekatan SCOR (Supply Chain Operations Reference). Dimana menurut Pujawan \& Mahendrawathi (2010) 5 proses inti yaitu plan, source, make deliver, dan return. Akan tetapi aktivitas rantai pasok pada PT. Petronika hanya sampai pada proses deliver saja. Setelah melakukan wawancara kepada pihak PT. Petronika, didapatkan aktivitas supply chain yang dapat dilihat pada tabel 5 berikut ini.

Tabel 5. Aktivitas SCOR PT. Petronika

\begin{tabular}{|c|l|}
\hline Process Area & \multicolumn{1}{|c|}{ Sub - Process/Kegiatan } \\
\hline \multirow{3}{*}{ Plan } & Perencanaan produksi \\
\cline { 2 - 2 } & $\begin{array}{l}\text { Pengendalian persediaan } \\
\text { material/bahan baku. }\end{array}$ \\
\hline
\end{tabular}

\begin{tabular}{|l|l|}
\hline \multirow{5}{*}{ Source } & $\begin{array}{l}\text { Pemilihan supplier alat } \\
\text { penunjang produksi }\end{array}$ \\
\cline { 2 - 2 } & $\begin{array}{l}\text { Pemesanan alat penunjang } \\
\text { produksi }\end{array}$ \\
\hline \multirow{5}{*}{ Make } & $\begin{array}{l}\text { Proses pengadaan material/bahan } \\
\text { baku }\end{array}$ \\
\cline { 2 - 2 } & $\begin{array}{l}\text { Menjalin kontrak kerjasama } \\
\text { dengan supplier }\end{array}$ \\
\hline & Pelaksanaan produksi. \\
\cline { 2 - 2 } & Quality Control \\
\cline { 2 - 2 } & Penerimaan order pelanggan \\
\cline { 2 - 2 } & Penjualan produk \\
\hline Deliver & Pengiriman produk ke pelanggan \\
\hline
\end{tabular}

Sumber : PT. Petronika

\section{Identifikasi Kejadian Risiko}

Kejadian risiko (Ei) merupakan semua kejadian yang mungkin timbul pada proses rantai pasok yang mengakibatkan kerugian pada perusahaan yang dapat diukur dengan skala severity. Severity adalah langkah pertama untuk menganalisa risiko yaitu menghitung seberapa besar dampak atau intensitas kejadian mempengaruhi proses operasional (Trenggonowati \& Pertiwi, 2017). Skala severity peneliti menggunakan nilai fuzzy.

Identifikasi kejadian risiko dan pengukuran dilakukan dengan cara penyusunan kuesioner berisi potensi - potensi kejadian risiko berdasarkan referensi penelitian terdahulu kemudian diisi oleh responden bagian expert yang telah ditentukan oleh perusahaan. Responden expert yang telah terpilih seperti penjelasan sebelumnya memiliki masing masing bobot yang berbeda. Penentuan bobot tiap team members (responden) ditentukan oleh pihak perusahaan. Untuk penjelasannya dapat dilihat sebagai berikut :

1. Team Members 1 (TM 1) adalah seorang responden yang memiliki jabatan sebagai Asisten Manajer pada perusahaan dimana memiliki bobot sebesar $40 \%$.

2. Team Members 2 (TM 2) adalah seorang responden yang memiliki jabatan sebagai Supervisor pada perusahaan dimana memiliki bobot sebesar $30 \%$.

3. Team Members 3 (TM 3) adalah seorang responden yang memiliki jabatan sebagai Foreman atau Staff pada perusahaan dimana memiliki bobot sebesar $20 \%$. 
4. Team Members 4 (TM 4) adalah seorang responden yang memiliki jabatan sebagai Pelaksana pada perusahaan dimana memiliki bobot sebesar $10 \%$.

Pemberian bobot tersebut ditentukan oleh perusahaan atas dasar pihak expert yang memiliki jabatan paling tertinggi sebagai responden dan memiliki pengalaman lama bekerja dalam perusahaan.
Berikut ini contoh perhitungan peringkat fuzzy terhadap faktor severity pada failure mode E1 :

$\tilde{R}_{1}^{S}=h_{1} \tilde{R}_{11}^{S}=40 \% \times[1,1,2,2]=[0.4,0.4,0,8$,

$0,8]$

$h_{2} \tilde{R}_{12}^{S}=30 \% \mathrm{x}[1,2,2,3]=[0.3,0.6,0.6,0,9]$

$h_{3} \tilde{R}_{13}^{S}=20 \% \times[8,9,9,10]=[1.6,1.8,1.8,2]$

$h_{4} \tilde{R}_{14}^{S}=10 \% \times[1,1,2,2]=[0.1,0.1,0.2,0.2]$

$\tilde{R}_{1}^{S}=\sum_{j=1}^{m} h_{j} \tilde{R}_{i j}^{S}=[2.4,2.9,3.4,3.9]$

Dengan perhitungan yang sama maka agregasi penilaian peringkat fuzzy terhadap faktor severity dapat dilihat pada tabel 6 .

Tabel 6. Kejadian Risiko (Risk Event) Dengan Skala Severity

\begin{tabular}{|c|c|c|}
\hline \multicolumn{2}{|r|}{ Failure Mode } & \multirow{2}{*}{ Severity } \\
\hline Code & Risk Event & \\
\hline E1 & Perubahan rencana produksi secara mendadak & {$[2.4,2.9,3.4,3.9]$} \\
\hline E2 & $\begin{array}{l}\text { Perencanaan kapasitas produksi yang tidak sesuai dengan yang } \\
\text { direncanakan }\end{array}$ & {$[2.4,2.9,3.4,3.9]$} \\
\hline E3 & Keterlambatan kedatangan bahan baku & {$[3.4,4.15,4.4,5.15]$} \\
\hline E4 & Kesalahan dalam memilih supplier & {$[3.4,4.4,4.4,5.4]$} \\
\hline E5 & Kualitas alat tidak sesuai dengan perjanjian & {$[6.6,7.6,7.6,8.6]$} \\
\hline E6 & Kesalahan pembelian barang & {$[6.7,7.6,7.6,8.5]$} \\
\hline E7 & Kuantitas bahan baku dari supplier tidak sesuai & {$[4.3,5.3,5.3,6.3]$} \\
\hline E8 & Ketersediaan bahan baku kurang & {$[3.5,4.25,4.5,5.25]$} \\
\hline E9 & Terhambatnya negosiasi dengan supplier & {$[3.6,4.6,4.6,5.6]$} \\
\hline E10 & Shutdown perusahaan & {$[2.8,3.3,3.8,4.3]$} \\
\hline E11 & Keterlambatan pelaksanaan produksi & {$[2.6,3.6,3.6,4.6]$} \\
\hline E12 & Terjadi kecelakaan saat proses produksi & {$[2.4,3.4,3.4,4.4]$} \\
\hline E13 & Ketidaksesuaian waktu proses produksi & {$[1.7,2.6,2.7,3.6]$} \\
\hline E14 & Proses produksi terhambat & {$[1.7,2.6,2.7,3.6]$} \\
\hline E15 & Ketidaksesuaian spesifikasi produk & {$[3,4,4,5]$} \\
\hline E16 & Produk rusak & {$[6.3,7.3,7.3,8.3]$} \\
\hline E17 & Proses order pelanggan terhambat & {$[2,3,3,4]$} \\
\hline E18 & Harga penjualan produk tidak stabil & {$[3.2,4.2,4.2,5.2]$} \\
\hline E19 & Kurangnya pemenuhan seluruh permintaan pelanggan & {$[2.3,3.3,3.3,4.3]$} \\
\hline E20 & Penjualan produk tidak memenuhi target & {$[3.3,4.3,4.3,5.3]$} \\
\hline E21 & Keterlambatan pengiriman & {$[5.4,6.4,6.4,7.4]$} \\
\hline E22 & Mengalami penyusutan produk & {$[5.2,6.2,6.2,7.2]$} \\
\hline
\end{tabular}




\section{Identifikasi Agen Risiko}

Agen risiko (Ai) merupakan factor apa saja yang dapat menyebabkan terjadinya kejadian risiko yang telah teridentifikasi yang diukur dengan menggunakan skala occurrence. Occurrence adalah kemungkinan bahwa risiko tersebut akan terjadi dan menghasilkan bentuk kegagalan selama proses operasional (Trenggonowati \& Pertiwi, 2017). Untuk skala occurrence, peneliti menggunkan nilai fuzzy.

Pada tahap ini dilakukan wawancara kepada bagian expert yang telah ditentukan sebelumnya, setelah itu hasil wawancara akan divalidasi dengan penyebaran kuesioner kepada responden yang telah dipilih. Seperti halnya pada identifikasi kejadian risiko diatas. Didapatkan contoh perhitungan peringkat fuzzy terhadap faktor occurence pada failure mode A1 :
$\tilde{R}_{1}^{O}=h_{1} \widetilde{R}_{11}^{O}=40 \% \times[8,9,10,10]=[3.2,3.6$,

4, 4]

$h_{2} \tilde{R}_{12}^{O}=30 \%$ x $[3,4,6,7]=[0.9,1.2,1.8,2.1]$

$h_{3} \tilde{R}_{13}^{O}=20 \%$ x $[8,9,10,10]=[1.6,1.8,2,2]$

$h_{4} \tilde{R}_{14}^{O}=10 \% \times[3,4,6,7]=[0.3,0.4,0.6,0.7]$

$\tilde{R}_{1}^{O}=\sum_{j=1}^{m} h_{j} \tilde{R}_{i j}^{O}=[6,7,8.2,8.8]$

Dengan perhitungan yang sama maka agregasi penilaian peringkat fuzzy terhadap faktor severity dan occurence pada semua failure mode dapat dilihat pada tabel 7 berikut ini.

Tabel 7. Agen Risiko (Risk Agent) Dengan Skala Occurrence

\begin{tabular}{|c|l|c|}
\hline \multicolumn{2}{|c|}{ Failure Mode } & \multirow{2}{*}{ Occurence } \\
\hline Code & \multicolumn{1}{|c|}{ Risk Agent } & {$[6,7,8.4,8.8]$} \\
\hline A1 & Kondisi pasar yang tidak stabil & {$[3.4,4.4,6.1,7.1]$} \\
\hline A2 & Ketersediaan bahan baku kurang & {$[2.8,3.8,5.7,6.7]$} \\
\hline A3 & Pengaturan stok produk jadi yang tidak seimbang & {$[3.8,4.9,7,8]$} \\
\hline A4 & Keterlambatan kedatangan bahan baku & {$[3.2,4.2,6.05,7.05]$} \\
\hline A5 & Keterlambatan jadwal bongkar bahan baku & {$[2.9,3.9,5.85,6.85]$} \\
\hline A6 & Tidak ada tempat parkir untuk kapal muatan bahan baku & {$[2.8,3.8,5,5.8]$} \\
\hline A7 & Perubahan jadwal produksi pihak supplier & {$[2,3,4.5,5.5]$} \\
\hline A8 & Supplier kurang konsisten dalam menjaga mutu produk & {$[1,1.5,2.5,3]$} \\
\hline A9 & Kurangnya penilaian terhadap pemilihan supplier & {$[1,1.5,2.5,3]$} \\
\hline A10 & Supplier tidak tepat waktu dalam pengiriman produk. & {$[1.8,2.2,3.6,4]$} \\
\hline A11 & Kuraang menguasai barang yang dijual & {$[2,2.5,4,4.5]$} \\
\hline A12 & Pihak supplier kurang teliti dalam pengecekan & {$[2,2.5,4,4.5]$} \\
\hline A13 & Kurangnya koordinasi dengan pihak supplier & {$[3.9,4.9,6.1,7.1]$} \\
\hline A14 & Terjadi penyusutan bahan baku saat proses pengiriman & {$[1.8,2.5,3.9,4.6]$} \\
\hline A15 & Kurangnya informasi mengenai spesifikasi produk yang akan diproses & {$[5.85,6.85,8.2,8.7]$} \\
\hline A16 & Kerusakan alat & {$[3,4,5.5,6.5]$} \\
\hline A17 & Tangki penyimpanan produk penuh & {$[5,6,7.1,7.7]$} \\
\hline A18 & Program perusahaan & {$[5.2,6.2,7.2,7.6]$} \\
\hline A19 & Pemadaman listrik & {$[3.4,4.4,6.1,7.1]$} \\
\hline A20 & Air limbah meningkat & \\
\hline A21 & Human error & \\
\hline
\end{tabular}




\begin{tabular}{|c|c|c|}
\hline A22 & Pipa steam terendam air & {$[5.2,6.2,7.2,7.6]$} \\
\hline A23 & Sering ganti filter & {$[5.25,6.25,7.5,8.5]$} \\
\hline A24 & Adanya produk cacat & {$[2,3,4.5,5.5]$} \\
\hline A25 & Waktu reaksi lama & {$[5,6,7.6,8.2]$} \\
\hline A26 & Spesifikasi bahan baku tidak sesuai & {$[1.8,2.8,4.2,5.2]$} \\
\hline A27 & Pengaturan suhu yang tidak tepat & {$[1.8,2.8,4.2,5.2]$} \\
\hline A28 & Pengaturan analisa reaksi yang tidak tepat & {$[2.4,3.4,5.1,6.1]$} \\
\hline A29 & Konsumsi energi dan gas alam lebih banyak & {$[3,4,6,7]$} \\
\hline A30 & Pengaturan reflux sulit & {$[3,4,6,7]$} \\
\hline A31 & Hasil analisa acid value (nilai keasaman) sulit dideteksi & {$[1.6,2.6,3.9,4.9]$} \\
\hline A32 & Mol ratio bahan baku tidak tepat & {$[1.6,2.6,3.9,4.9]$} \\
\hline A33 & Adanya bahan yang tidak diinginkan & {$[2.8,3.8,5.7,6.7]$} \\
\hline A34 & Pemborosan pemakaian NAOH & {$[2.2,3.2,4.8,5.8]$} \\
\hline A35 & Kualitas produk menurun & {$[1.4,2.4,3.6,4.6]$} \\
\hline A36 & Switch produk & {$[2,3,4.5,5.5]$} \\
\hline A37 & Alat transportasi produk tidak bersih & {$[1.2,1.8,2.5,3.1]$} \\
\hline A38 & Tangki proses produksi tidak bersih & {$[1.2,1.8,2.5,3.1]$} \\
\hline A39 & Formulasi bahan baku yang tidak tepat & {$[1.8,2.8,4.2,5.2]$} \\
\hline A40 & Pengaturan NAOH yang tidak tepat & {$[1.8,2.8,4.2,5.2]$} \\
\hline A41 & Canceled PO (purchase order) & {$[1,2,3,4]$} \\
\hline A42 & Sistem administrasi kurang tertata & {$[1,2,3,4]$} \\
\hline A43 & Perbedaan penawaran harga setiap pelanggan & {$[4.9,5.9,7.1,7.6]$} \\
\hline A44 & Judgment perusahaan & {$[1.8,2.8,4.2,5.2]$} \\
\hline A45 & Naik turunnya harga dolar & {$[5.6,6.6,7.8,8.7]$} \\
\hline A46 & Tidak tercapainya target produksi & {$[1,2,3,4]$} \\
\hline A47 & Perbedaan alat timbang antara perusahaan dan konsumen & {$[1.6,2.6,3.9,4.9]$} \\
\hline A48 & Customer membeli produk ke kompetitor & {$[5.1,6.1,7.4,8.4]$} \\
\hline A49 & Keterbatasan armada & {$[3.7,4.7,6.3,7.3]$} \\
\hline A50 & Kemacetan jalan lalu lintas & {$[4.1,5.1,6.4,7.4]$} \\
\hline A51 & Pemuaian produk & {$[1.2,2.2,3.3,4.3]$} \\
\hline A52 & Kebocoran tangki armada & {$[2.4,3.4,5.1,6.1]$} \\
\hline
\end{tabular}

\section{House of Risk Fase 1}

House of Risk (HOR) fase 1 digunakan untuk menentukan sumber risiko mana yang diprioritaskan untuk dilakukan tindakan pencegahan. Hal pertama yang dilakukan yaitu identifikasi korelasi. Hubungan antara agen risiko dan kejadian risiko lainnya diidentifikasi dan diberi nilai $0,1,3$ atau sebagai tanda dari masing - masing hubungan korelasi.
Langkah selanjutnya adalah menghitung Agregate Risk Potential (ARP) yang diperoleh dari hasil perkalian probabilitas sumber risiko dan dampak kerusakan terkait risiko itu terjadi. Setelah melakukan identifikasi korelasi dan melakukan perhitungan Agregate Risk Potential (ARP), maka langkah terakhir dalam metode HOR Fase 1 adalah membuat gambar HOR Fase 1 dengan menggabungkan data kejadian risiko, agen risiko, korelasi dan hasil 
perhitungan Agregate Risk Potential (ARP) kedalam sebuah tabel.

Dalam perhitungan ARP digunakan rumus sebagai berikut.

$$
\mathrm{ARP}_{\mathrm{j}}=\mathrm{O}_{\mathrm{j}} \sum \mathrm{S}_{\mathrm{i}} \mathrm{R}_{\mathrm{ij}}
$$

Dengan menggunakan rumus diatas, berikut didapatkan nilai ARP pada Risk Agent (A1).

$\mathrm{ARP}_{1}=\mathrm{S}_{1} \mathrm{R}_{11}=[2.4,2.9,3.4,3.9] \times 9=[21.6$, $26.1,30.6,35.1]$

$\mathrm{S}_{2} \mathrm{R}_{21}=[2.4,2.9,3.4,3.9] \times 1=[2.4$, $2.9,3.4,3.9]$

$\mathrm{S}_{3} \mathrm{R}_{31}=[3.4,4.15,4.4,5.15] \times 0=[0$, $0,0,0]$

$\mathrm{S}_{4} \mathrm{R}_{41}=[3.4,4.4,4.4,5.4] \times 0=[0,0$, $0,0]$

$\mathrm{S}_{5} \mathrm{R}_{51}=[6.6,7.6,7.6,8.6] \times 0=[0,0$, $0,0]$

$\mathrm{S}_{6} \mathrm{R}_{61}=[6.7,7.6,7.6,8.5] \times 0=[0,0$, $0,0]$

$\mathrm{S}_{7} \mathrm{R}_{71}=[4.3,5.3,5.3,6.3] \times 0=[0,0$, $0,0]$

$\mathrm{S}_{8} \mathrm{R}_{81}=[3.5,4.25,4.5,5.25] \times 0=[0$, $0,0,0]$

$\mathrm{S}_{9} \mathrm{R}_{91}=[3.6,4.6,4.6,5.6] \times 0=[0,0$, $0,0]$

$\mathrm{S}_{10} \mathrm{R}_{101}=[2.8,3.3,3.8,4.3] \times 10=[0$, $0,0,0]$

$\mathrm{S}_{11} \mathrm{R}_{111}=[2.6,3.6,3.6,4.6] \times 0=[0$, $0,0,0]$

$\mathrm{S}_{12} \mathrm{R}_{121}=[2.4,3.4,3.4,4.4] \times 0=[0$, $0,0,0]$
$S_{13} R_{131}=[1.7,2.6,2.7,3.6] \times 0=[0$, $0,0,0]$

$\mathrm{S}_{14} \mathrm{R}_{141}=[1.7,2.6,2.7,3.6] \times 0=[0$, $0,0,0]$

$S_{15} R_{151}=[3,4,4,5] \times 0=[0,0,0,0]$ $\mathrm{S}_{16} \mathrm{R}_{161}=[6.3,7.3,7.3,8.3] \times 0=[0$, $0,0,0]$

$\mathrm{S}_{17} \mathrm{R}_{171}=[2,3,3,4] \times 0=[0,0,0,0]$

$\mathrm{S}_{18} \mathrm{R}_{181}=[3.2,4.2,4.2,5.2] \times 0=[0$, $0,0,0]$

$\mathrm{S}_{19} \mathrm{R}_{191}=[2.3,3.3,3.3,4.3] \times 0=[0$, $0,0,0]$

$\mathrm{S}_{20} \mathrm{R}_{201}=[3.3,4.3,4.3,5.3] \times 0=[0$, $0,0,0]$

$S_{21} R_{211}=[5.4,6.4,6.4,7.4] \times 0=[0$, $0,0,0]$

$\mathrm{S}_{22} \mathrm{R}_{221}=[5.2,6.2,6.2,7.2] \times 0=[0$, $0,0,0]$

$$
\begin{aligned}
\mathrm{ARP}_{1} & =\mathrm{O}_{1} \sum \mathrm{S}_{\mathrm{i}} \mathrm{R}_{\mathrm{ij}} \\
& =[6,7,8.4,8.8] \times[24,29,34,39] \\
& =[144,203,256.6,343.2]
\end{aligned}
$$

Karena nilai ARP masih dalam bentuk fuzzy maka dilakukan defuzzyfikasi menggunakan metode centroid.

$$
\begin{aligned}
& \mathrm{ARP}_{1}=\frac{a+b+c+d}{4} \\
& \mathrm{ARP}_{1}=\frac{144+203+256.6+343.2}{4} \\
& \mathrm{ARP}_{1}=236.7
\end{aligned}
$$

Dengan cara yang sama maka gambar HOR Fase 1 dapat dilihat sebagai beirkut 


\begin{tabular}{|c|c|c|c|c|c|c|c|c|c|c|c|c|c|}
\hline & \multicolumn{12}{|c|}{ Risk Agers (si) } & \multirow[b]{2}{*}{$\begin{array}{c}\text { Severity of Risk Eventi } \\
\text { (Si) }\end{array}$} \\
\hline Risk Evert (gij) & Al & $A 2$ & A3 & $\mathrm{A} 4$ & $A_{5}$ & A6 & A7 & AB & A9 & $\mathrm{A} 10$ & All & $\mathrm{A} 12$ & \\
\hline $\mathrm{El}$ & 9 & 9 & 9 & 9 & 1 & 1 & 3 & 0 & 0 & 1 & 0 & 0 & {$[2.4,2.9,3.4,3.9]$} \\
\hline E2 & 1 & 9 & 3 & 9 & 1 & 1 & 3 & 0 & 0 & I & 0 & 0 & {$[2.4,2.9,3.4,3.9]$} \\
\hline E3 & 0 & 0 & $\theta$ & 1 & 9 & 9 & 9 & 0 & 0 & 3 & 0 & 0 & {$[3.4,4.15,4.4,5.15]$} \\
\hline E4 & 0 & 0 & 0 & 0 & 0 & 0 & 0 & 9 & 9 & 9 & 9 & 3 & {$[3.4,4.4,4.4,5.4]$} \\
\hline E5 & 0 & 0 & 0 & 0 & 0 & 0 & 0 & 0 & 3 & 0 & 3 & 9 & {$[6.6,7.6,7.6 .8 .67$} \\
\hline E6 & 0 & 0 & 0 & 0 & 0 & 0 & 0 & 0 & 3 & 0 & 0 & 0 & {$[67,7.6,7.6,8.5\rceil$} \\
\hline E7 & 0 & 9 & 0 & 0 & 0 & 0 & 9 & 0 & 3 & 0 & 0 & 9 & {$[4,3,5,3,5,3,6.3]$} \\
\hline E\& & 0 & 1 & 0 & 9 & 0 & 0 & 9 & 0 & 0 & 3 & 0 & 0 & {$[3.5,4.25,4.5,5.25]$} \\
\hline $\mathrm{E} 9$ & 0 & 0 & 0 & 0 & 0 & 0 & 0 & 1 & 9 & $\mathrm{I}$ & 0 & 0 & {$[3.6,4.6,4.6,5.6]$} \\
\hline E10 & 0 & 9 & 0 & 9 & 0 & 0 & 0 & 0 & 0 & $\mathrm{I}$ & 0 & 0 & {$[2.8,3.3,3.8 .4 .3]$} \\
\hline E11 & 0 & 3 & $\theta$ & 9 & 0 & $\theta$ & 0 & 0 & 0 & 0 & 0 & 0 & {$[2.6,3.6,3.6,4.6]$} \\
\hline E12 & 0 & 0 & 0 & 0 & 0 & 0 & 0 & 0 & 0 & 0 & 0 & 0 & {$[2.4,3.4,3.4,4.47$} \\
\hline E13 & 0 & 9 & 1 & 9 & 0 & 0 & 1 & 0 & 0 & 3 & 0 & 0 & {$[1,7,2.6,27,3.6]$} \\
\hline E14 & 0 & 9 & 0 & 9 & 0 & 0 & 0 & 0 & 0 & $\mathrm{I}$ & 0 & 0 & {$[1,7,2.6,2.7,3.6]$} \\
\hline E15 & 0 & 0 & 0 & 0 & 0 & 0 & 0 & 0 & 0 & 0 & 0 & 0 & {$[3,4,4,5]$} \\
\hline E16 & 0 & 0 & $\theta$ & 0 & 0 & $\theta$ & 0 & 0 & 0 & 0 & 0 & 0 & {$[6.3,73,73,8.31$} \\
\hline E1? & 0 & 0 & 0 & 0 & 0 & 0 & 0 & 0 & 0 & 0 & 0 & 0 & {$[2,3,3,4]$} \\
\hline E18 & 0 & 0 & 0 & 0 & 0 & 0 & 0 & 0 & 0 & 0 & 0 & 0 & {$[3,2,42,42,52]$} \\
\hline E19 & 0 & 1 & 0 & 1 & 0 & 0 & 0 & 0 & 0 & 0 & 0 & 0 & {$[2.3,3.3,3,3,43]$} \\
\hline E20 & 0 & 0 & 0 & 0 & 0 & 0 & 0 & 0 & 0 & 0 & 0 & 0 & {$[3,3,4,3,43,5,3]$} \\
\hline E21 & 0 & 0 & $\theta$ & 0 & 0 & $\theta$ & 0 & 0 & 0 & 0 & 0 & 0 & {$[5,4,6,4,6,4,3,4]$} \\
\hline E22 & 0 & 0 & 0 & 0 & 0 & 0 & 0 & 0 & 0 & 0 & 0 & 0 & {$[5.2,62,62,7.2]$} \\
\hline Oscureace of Agent $j$ & $\begin{array}{c}{[6.7,8.4 .} \\
8.8]\end{array}$ & $\begin{array}{l}{[3.4,4.4,} \\
6.1,7.1]\end{array}$ & $\begin{array}{l}{[2.8 .3 .8,} \\
5.7,67]\end{array}$ & $\begin{array}{c}{[3.8,4.9 .7} \\
8]\end{array}$ & $\begin{array}{c}{[3.2 .4 .2,} \\
6.05 \\
7.051\end{array}$ & $\begin{array}{l}{[2.9,3.9} \\
5.85,6.85]\end{array}$ & $\begin{array}{c}{[2.8,3.8,5} \\
5.8]\end{array}$ & $\begin{array}{c}{[2,3,4.5} \\
5.5]\end{array}$ & {$[1,1,5,25$} & {$[1,1,5,25$} & $\begin{array}{c}{[1.8,22,} \\
3.6,4]\end{array}$ & {$\left[\begin{array}{c}{[2,2.5,4} \\
4.5]\end{array}\right.$} & \\
\hline $\begin{array}{c}\text { Agregst Risk of Potertial } \\
\mathrm{j}\end{array}$ & 236,7 & $1.113,9$ & 251,9 & 1.337 .1 & 239,3 & 913,3 & 567,9 & 174,5 & $1.193,4$ & 193,3 & 187,6 & 433,3 & \\
\hline Priarivy ramk of Agent & 27 & 4 & 22 & 2 & 26 & 5 & 7 & 37 & 3 & 30 & 33 & 9 & \\
\hline
\end{tabular}

Gambar 3. House Of Risk Fase 1 


\begin{tabular}{|c|c|c|c|c|c|c|c|c|c|c|c|c|c|}
\hline \multirow[b]{2}{*}{ Risk Elear (Ej) } & \multicolumn{12}{|c|}{ Risk Agent (Si) } & \multirow[b]{2}{*}{$\begin{array}{c}\text { Severity of Risk Event } \\
\text { (Si) }\end{array}$} \\
\hline & A13 & A14 & A15 & Al6 & Al7 & A18 & A19 & $A 20$ & A.21 & $\mathrm{A} 22$ & $\mathrm{~A} 23$ & $\mathrm{~A} 24$ & \\
\hline El & 1 & 3 & 0 & 3 & 3 & 0 & 0 & 0 & 0 & $\theta$ & 0 & 0 & {$[24,2.9,3.4,3.9]$} \\
\hline E2 & 1 & 3 & 0 & 0 & 3 & 0 & 0 & 0 & 0 & 0 & 0 & 0 & {$[2.4,2.9,3.4,3.9]$} \\
\hline E3 & 1 & 0 & 0 & 0 & 0 & 0 & 0 & 0 & 0 & 0 & 0 & 0 & {$[3.4,4.15,4.4,5.15]$} \\
\hline E4 & I & 0 & 0 & 0 & 0 & 0 & 0 & 0 & 0 & 0 & 0 & 0 & {$[3.4,4.4,4.4,5.4]$} \\
\hline E5 & 3 & 0 & 0 & 0 & 0 & 0 & 0 & 0 & 0 & $\theta$ & 0 & 0 & {$[6.6,7.6,7.6,8.6\rceil$} \\
\hline E6 & 9 & 0 & 0 & 0 & 0 & 0 & 0 & 0 & 0 & 0 & 0 & 0 & {$[6.7,7.6,7.6,8.5]$} \\
\hline E7 & 3 & 9 & 0 & 0 & 0 & 0 & 0 & 0 & 0 & $\theta$ & 0 & 0 & {$[4,3,5,3,5,3,6.3]$} \\
\hline E8 & 3 & 9 & 0 & 0 & 0 & 0 & 0 & 0 & 0 & 0 & 0 & 0 & {$[3.5,4.25,45,525]$} \\
\hline E9 & 3 & 0 & 9 & 0 & 0 & 0 & 0 & 0 & 0 & 0 & 0 & 0 & {$[3.6,4.6,4.6,5.6]$} \\
\hline E10 & 0 & 0 & 0 & 3 & 9 & 9 & 9 & 9 & 0 & 0 & 0 & 0 & {$[2.8,3.3,3.8,4.3]$} \\
\hline E11 & 0 & 0 & 0 & 9 & 0 & 0 & 0 & 0 & 0 & 0 & 0 & 0 & {$[2.6,3.6,3.6 .4 .67$} \\
\hline E12 & 0 & 0 & 0 & 0 & 0 & 0 & 0 & 0 & 9 & 0 & 0 & 0 & {$[2,4,3,4,3,4,4,4]$} \\
\hline E13 & 0 & 0 & 0 & 9 & 0 & 0 & 0 & 0 & 0 & 0 & 0 & 0 & {$[1.7,2.6,2.7,3.6]$} \\
\hline E14 & 0 & 0 & 0 & 9 & 1 & 0 & 3 & 0 & 1 & 9 & 9 & 9 & {$[1.7,2.6,2.7,3.6]$} \\
\hline E15 & 0 & 0 & 0 & 9 & 0 & 0 & 0 & 0 & 0 & 0 & 9 & 0 & {$[3,4,4,5]$} \\
\hline El6 & 0 & 0 & 0 & 9 & 0 & 0 & 0 & 0 & 9 & 0 & 0 & 9 & $\lceil 6.3,73,73,8.31$ \\
\hline E17 & 0 & 0 & 0 & 0 & 0 & 0 & 0 & 0 & 0 & 0 & 0 & 0 & {$[2,3,3,4]$} \\
\hline E18 & 0 & 0 & 0 & 0 & 0 & 0 & 0 & 0 & 0 & 0 & 0 & 0 & {$[3.2,42,42,5.2]$} \\
\hline E19 & 0 & 0 & 0 & 0 & 0 & 0 & 0 & 0 & 0 & $\theta$ & 0 & 0 & {$[2,3,3,3,3,4,43]$} \\
\hline E20 & 0 & 0 & 0 & 0 & 0 & 0 & 0 & 0 & 0 & 0 & 0 & 0 & {$[3,3,43,43,5,3]$} \\
\hline E21 & 0 & 0 & 0 & 0 & 0 & 0 & 0 & 0 & 9 & 0 & 0 & 0 & {$[5.4,6.4,6.4,7.4]$} \\
\hline E22 & 0 & 0 & 0 & 0 & 0 & 0 & 0 & 0 & 0 & 0 & 0 & 0 & {$[5.2,62,62,3.27$} \\
\hline Ascureasg of -Agent $j$ & $\begin{array}{c}{[2,25,4,} \\
4.5]\end{array}$ & $\begin{array}{l}{[3.9 .4 .9,} \\
6.1,7.1]\end{array}$ & $\begin{array}{l}{[1.8,2.5 \text {, }} \\
3.9,4.6]\end{array}$ & $\begin{array}{l}{[5.85,6.85} \\
8.2,8.7]\end{array}$ & $\begin{array}{c}{[3.4,5.5} \\
6.5]\end{array}$ & $\begin{array}{l}{[5,6,7.1 .} \\
7.7]\end{array}$ & {$[5.2,6.2$,} & $\begin{array}{l}{[3.4,4.4,} \\
6.1,7.1]\end{array}$ & $\begin{array}{l}{[2.3 .3 .3 .3} \\
4.8,5.8]\end{array}$ & $\begin{array}{l}{[5.2 .6 .2,} \\
7.2,7.6]\end{array}$ & $\begin{array}{c}{[5.25,} \\
6.25,7.5 \\
8.5]\end{array}$ & $\begin{array}{c}{[2,3,4.5 .} \\
5.5]\end{array}$ & \\
\hline Agregst Risk̀ of Potential & 499 & 590,7 & 138,8 & $1.397,5$ & 266,2 & 215 & 267.7 & 174,9 & 417,3 & 161,5 & 405,6 & 351,3 & \\
\hline Priaris rank of .Agert & 8 & 6 & 43 & I & 20 & 28 & 19 & 36 & 10 & 38 & 11 & 12 & \\
\hline
\end{tabular}

Gambar 3. House Of Risk Fase 1 (Lanjutan) 


\begin{tabular}{|c|c|c|c|c|c|c|c|c|c|c|c|c|c|}
\hline \multirow[b]{2}{*}{ Risk Elent (Gi) } & \multicolumn{12}{|c|}{ Risk Agent (Si) } & \multirow[b]{2}{*}{$\begin{array}{c}\text { Severity of Risk Event if } \\
\text { (Si) }\end{array}$} \\
\hline & A25 & A 26 & $\mathrm{~A} 23$ & A28 & $A 29$ & A30 & A31 & $\mathrm{A} 32$ & A33 & A34 & $A 35$ & A36 & \\
\hline EI & 0 & 0 & 0 & 0 & 0 & 0 & 0 & 0 & 0 & 0 & 0 & 0 & {$[2.4,2.9,3.4,3.91$} \\
\hline E2 & 0 & 0 & 0 & 0 & 0 & 0 & 0 & 0 & 0 & 0 & 0 & 0 & {$[2.4,2.9,3.4,3.9]$} \\
\hline E3 & 0 & 0 & 0 & 0 & 0 & 0 & 0 & 0 & 0 & $\theta$ & 0 & 0 & {$[3.4,4.15,4.4,5.15\rceil$} \\
\hline E4 & 0 & 0 & 0 & 0 & 0 & 0 & 0 & 0 & 0 & 0 & 0 & 0 & {$[3.4,4.4,4.4,5.4]$} \\
\hline E5 & 0 & 0 & 0 & 0 & 0 & 0 & 0 & 0 & 0 & 0 & 0 & 0 & $\lceil 6.6,7.6,3.6,8.61$ \\
\hline E6 & 0 & 0 & 0 & 0 & 0 & 0 & 0 & 0 & 0 & 0 & 0 & 0 & $\lceil 6.7,7.6,7.6,8.51$ \\
\hline E7 & 0 & 0 & 0 & 0 & 0 & 0 & 0 & 0 & 0 & 0 & 0 & 0 & {$[4,3,5,3,53,6.31$} \\
\hline E8 & 0 & 0 & 0 & 0 & 0 & 0 & 0 & 0 & 0 & 0 & 0 & 0 & {$[3.5,4.25,4.5,5.25]$} \\
\hline $\mathrm{E} 9$ & 0 & 0 & 0 & 0 & 0 & 0 & 0 & 0 & 0 & 0 & 0 & 0 & {$[3.6,4.6,4.6,5.6]$} \\
\hline E10 & 0 & 0 & 0 & 0 & 0 & 0 & 0 & 0 & 0 & 0 & 0 & 0 & {$[2.8,3.3,3.8,4.31$} \\
\hline E11 & 0 & 0 & 0 & 0 & 0 & 0 & 0 & 0 & 0 & 0 & 0 & 0 & {$[2.6,3.6,3.6,4.6\rceil$} \\
\hline E12 & 0 & 0 & 0 & 0 & 0 & 0 & 0 & 0 & 0 & 0 & 0 & 0 & {$[2,4,3,4,3,4,4,47$} \\
\hline E13 & 0 & 0 & 0 & 0 & 0 & 0 & 0 & 0 & 0 & 0 & 0 & 0 & $\lceil 17,2.6,2.7,3.6\rceil$ \\
\hline E14 & 0 & 0 & 0 & 0 & 0 & 0 & 0 & 0 & 0 & $\theta$ & 0 & 0 & $\lceil 1.7,2.6,2.7,3.6\rceil$ \\
\hline E15 & 9 & 9 & 9 & 9 & 9 & 9 & 9 & 9 & 9 & 9 & 9 & 0 & {$[3,4,4,5]$} \\
\hline E16 & 0 & 0 & 0 & 0 & 0 & 0 & 0 & 0 & 0 & 0 & 0 & 9 & {$[6.3,73,73,8.31$} \\
\hline $\mathrm{E} 17$ & 0 & 0 & 0 & 0 & 0 & 0 & 0 & 0 & 0 & 0 & 0 & 0 & {$[2,3,3,4]$} \\
\hline E18 & 0 & 0 & 0 & 0 & 0 & 0 & 0 & 0 & 0 & 0 & 0 & 0 & {$[32,42,42,52]$} \\
\hline E19 & 0 & 0 & 0 & 0 & 0 & 0 & 0 & 0 & 0 & 0 & 0 & 0 & $\lceil 2.3,3,3,3,3,4,3\rceil$ \\
\hline E20 & 0 & 0 & 0 & 0 & 0 & 0 & 0 & 0 & 0 & $\theta$ & 0 & 0 & {$[3,3,43,4,3,5,3]$} \\
\hline E21 & 0 & 0 & 0 & 0 & 0 & 0 & 0 & 0 & 0 & 0 & 0 & 0 & {$[5.4,6.4,6.4,3.4]$} \\
\hline E22 & 0 & 0 & 0 & 0 & 0 & 0 & 0 & 0 & 0 & 0 & 0 & 0 & {$[5.2,62,62,72\rceil$} \\
\hline Ascuserse of Agent $j$ & $\begin{array}{c}{[5,6,7.6} \\
8.2]\end{array}$ & $\begin{array}{l}{[1.8,2.8,} \\
4.2,5.2] \\
\end{array}$ & $\begin{array}{l}{[1.8,2.8,} \\
4.2,5.2]\end{array}$ & $\begin{array}{l}{[2.4,3.4} \\
5.1,6.1]\end{array}$ & $\begin{array}{c}{[3,4,6,} \\
7]\end{array}$ & {$[3,4,6,7]$} & $\begin{array}{l}{[1.6 .2 .6} \\
3.9,4.9]\end{array}$ & $\begin{array}{l}{[1.6,2.6} \\
39,49] \\
\end{array}$ & $\begin{array}{l}{[2.8,3.8,} \\
5.3,6.7]\end{array}$ & $\begin{array}{l}2.2 .3 .2 \\
4.8,5.8] \\
\end{array}$ & $\begin{array}{l}{[1.4,2.4,} \\
3.6,4.6]\end{array}$ & $\begin{array}{c}{[2,3.4 .5} \\
5.5]\end{array}$ & \\
\hline 45regst Risk of Potential & 248,4 & 314,9 & 314,9 & 161,3 & 189 & 189 & 124,4 & 124,4 & 179,8 & 152,1 & 115,2 & 254,25 & \\
\hline Priaridy rank of Agent & 23 & 15 & 16 & 39 & 31 & 32 & 46 & 47 & 34 & 41 & 48 & 21 & \\
\hline
\end{tabular}

Gambar 3. House Of Risk Fase 1 (Lanjutan) 


\begin{tabular}{|c|c|c|c|c|c|c|c|c|c|c|c|c|c|}
\hline \multirow[b]{2}{*}{ Risk Evers (Gij) } & \multicolumn{12}{|c|}{ Risk Agrent (si) } & \multirow[b]{2}{*}{$\begin{array}{c}\text { Severity of Risk Eventi } \\
\text { (ii) }\end{array}$} \\
\hline & A.37 & A.38 & A39 & A 40 & $A 41$ & A42 & A43 & A44 & A45 & A46 & $A 47$ & $A 48$ & \\
\hline $\mathrm{E} 1$ & 0 & 0 & 0 & 0 & 0 & 0 & 0 & 0 & 0 & 0 & 0 & 0 & {$[2.4,2.9,3.4 .3 .9]$} \\
\hline E2 & 0 & 0 & $\theta$ & 0 & 0 & $\theta$ & 0 & 0 & 0 & 0 & 0 & 0 & {$[2.4,2.9,3.4,3.9]$} \\
\hline E3 & 0 & 0 & 0 & 0 & 0 & 0 & 0 & 0 & 0 & 0 & 0 & 0 & {$[3.4,4.15,4.4,5.15]$} \\
\hline E4 & 0 & 0 & 0 & 0 & 0 & 0 & 0 & 0 & 0 & 0 & 0 & 0 & {$[3,4,4,4,4,4,5,4]$} \\
\hline E5 & 0 & 0 & 0 & 0 & 0 & 0 & 0 & 0 & 0 & 0 & 0 & 0 & {$[6.6,7.6,7.6,8.6]$} \\
\hline E6 & 0 & 0 & $\theta$ & 0 & 0 & $\theta$ & 0 & 0 & 0 & 0 & 0 & 0 & {$[6.7,7.6,3.6,8.5]$} \\
\hline E7 & 0 & 0 & $\theta$ & 0 & 0 & 0 & 0 & 0 & 0 & 0 & 0 & 0 & {$[4.3,5.3,5.3,63]$} \\
\hline ES & 0 & 0 & 0 & 0 & 0 & 0 & 0 & 0 & 0 & 9 & 0 & 0 & {$[3.5,4.25,45,525]$} \\
\hline E9 & 0 & 0 & 0 & 0 & 0 & 0 & 0 & 0 & 0 & 0 & 0 & 0 & {$[3.6,4.6,4.6,5.6]$} \\
\hline E10 & 0 & 0 & 0 & 0 & 0 & 0 & 0 & 0 & 0 & 9 & 0 & 0 & {$[2.8,3.3,3.8,4.3]$} \\
\hline E11 & 0 & 0 & 0 & 0 & 0 & 0 & 0 & 0 & 0 & 0 & 0 & 0 & {$[2.6 .3 .6,3.6 .4 .6]$} \\
\hline E12 & 0 & 0 & 0 & 0 & 0 & 0 & 0 & 0 & 0 & 0 & 0 & 0 & {$[2.4,3.4,3.4 .4 .4]$} \\
\hline E13 & 0 & 0 & $\theta$ & 0 & 0 & 0 & 0 & 0 & 0 & 0 & 0 & 0 & {$[1,7,2.6,2.7,3.6]$} \\
\hline E14 & 1 & 1 & 0 & 0 & 0 & 0 & 0 & 0 & 0 & 0 & 0 & 0 & {$[1.7,2.6,2.7,3.6]$} \\
\hline E15 & 9 & 9 & 9 & 9 & 0 & 0 & 0 & 0 & 0 & 0 & 0 & 0 & {$[3,4,4,5]$} \\
\hline E16 & 0 & 0 & 0 & 0 & 0 & 0 & 0 & 0 & 0 & 0 & 0 & 0 & {$[6.3,73,73,83]$} \\
\hline $\mathrm{E} 17$ & 0 & 0 & $\theta$ & 0 & 9 & 9 & 0 & 0 & 0 & 0 & 0 & 0 & {$[2,3,3,4]$} \\
\hline E18 & 0 & 0 & 0 & 0 & 0 & 0 & 9 & 9 & 9 & 0 & 0 & 0 & {$[3,2,42,42,52]$} \\
\hline E19 & 0 & 0 & 0 & 0 & 0 & 0 & 0 & 0 & 0 & 9 & 9 & 0 & {$[2.3,3.3,3.3,4.3]$} \\
\hline E20 & 0 & 0 & 0 & 0 & 9 & 0 & 0 & 0 & 0 & 9 & 0 & 9 & {$[3,3,43,43,5.3]$} \\
\hline E21 & 0 & 0 & 0 & 0 & 0 & 0 & 0 & 0 & 0 & 0 & 0 & 0 & {$[5.4,6.4,6.4,7.4]$} \\
\hline E22 & 0 & 0 & 0 & 0 & 0 & 0 & 0 & 0 & 0 & 0 & 0 & 0 & $\lceil 52,62,62,72\rceil$ \\
\hline Accureace of Agent $j$ & $\begin{array}{l}{[1.2,1.8,} \\
2.5,3.1]\end{array}$ & $\begin{array}{l}{[1.2 .1 .8} \\
2.5,3.1]\end{array}$ & $\begin{array}{l}{[1.8,2.8,} \\
4.2,5.2]\end{array}$ & $\begin{array}{l}{[1.8,2.8,} \\
4.2,5.2]\end{array}$ & {$[1,2,3$} & {$[1,2,3,4]$} & $\begin{array}{l}{[4.9 .5 .99} \\
7.1,7.6]\end{array}$ & $\begin{array}{l}{[1.8,28,} \\
42,5.2]\end{array}$ & $\begin{array}{l}{[5.6,6.6,} \\
7.8,8.7]\end{array}$ & {$[1,2,3,4]$} & $\begin{array}{l}{[1,6,2.6,} \\
39,49]\end{array}$ & $\begin{array}{l}{[5.1,61,} \\
7.4,84]\end{array}$ & \\
\hline Agreger Risk of Potentiai & 87,8 & 87.8 & 133,7 & 133,7 & 177.7 & 74,2 & 247 & 139,9 & 278,2 & 212,8 & 103,9 & 268,7 & \\
\hline Priarisy rank of . Agent & 50 & 51 & 44 & 45 & 35 & 52 & 24 & 42 & 17 & 29 & 49 & 18 & \\
\hline
\end{tabular}

Gambar 3. House Of Risk Fase 1 (Lanjutan) 


\begin{tabular}{|c|c|c|c|c|c|}
\hline \multirow[b]{2}{*}{ Risk Event (Gi) } & \multicolumn{4}{|c|}{ Risk Agent (Ai) } & \multirow[b]{2}{*}{ Severizy of Risk Event $i$ (Si) } \\
\hline & $A 49$ & A50 & A51 & A52 & \\
\hline EI & 0 & 0 & 0 & 0 & {$[2.4,29,3.4,3.9]$} \\
\hline E2 & 0 & 0 & 0 & 0 & {$[24,29,3,4,3.9]$} \\
\hline E3 & 0 & 0 & 0 & 0 & {$[3.4,4.15,4.4,5.15]$} \\
\hline E4 & 0 & 0 & 0 & 0 & {$[3.4,4.4,4.4,5.4]$} \\
\hline E5 & 0 & 0 & 0 & 0 & {$[6.6,7.6,7.6,8.6]$} \\
\hline E6 & 0 & 0 & 0 & 0 & {$[6.7,7.6,7.6,85]$} \\
\hline E? & 0 & 0 & 0 & 0 & {$[4,3,53,53,63]$} \\
\hline E8 & 0 & 0 & 0 & 0 & {$[3.5,4.25,45,5.25]$} \\
\hline E9 & 0 & 0 & 0 & 0 & {$[3.6,4.6,4.6,5.6]$} \\
\hline E10 & 0 & 0 & 0 & 0 & {$[2.8,3,3,3.8,4,3]$} \\
\hline E11 & 0 & 0 & 0 & 0 & {$[2.6,3.6,3.6 .4 .6]$} \\
\hline E12 & 0 & 0 & 0 & 0 & {$[2,4,3,4,3,4,4,4]$} \\
\hline E13 & 0 & 0 & 0 & 0 & {$[1.7,26,27,3.6]$} \\
\hline E14 & 0 & 0 & 0 & 0 & {$[1.7,2.6,27,3.6]$} \\
\hline E15 & 0 & 0 & 0 & 0 & {$[3,4,4,5]$} \\
\hline E16 & 0 & 0 & 0 & 0 & {$[63,73,73,83]$} \\
\hline E17 & 0 & 0 & 0 & 0 & {$[2,3,3,4]$} \\
\hline E18 & 0 & 0 & 0 & 0 & {$[32,42,42,52]$} \\
\hline E19 & 0 & 0 & 0 & 0 & {$[23,3,3,3,4,43]$} \\
\hline E20 & 0 & 0 & 0 & 0 & {$[3.3,43,43,5 \cdot 3]$} \\
\hline E21 & 9 & 9 & 0 & 0 & {$[5.4,6.4,6.4,7.4]$} \\
\hline E22 & 0 & 0 & 9 & 9 & {$[52,62,62,72]$} \\
\hline Q acturesce of Agenti & {$[3.7 .4 .7,6.3,7.31$} & {$[4.1,5.1,6.4,7.4]$} & $\lceil 1.2,22,3,3,4.3\rceil$ & {$[2.4,3.4,5.1,6.1]$} & \\
\hline fgregst Risk of Potentiai & 324,9 & 338,6 & 160,4 & 245,5 & \\
\hline Priaridy ranc of .Agent & 14 & 13 & 40 & 25 & \\
\hline
\end{tabular}

Gambar 3. House Of Risk Fase 1 (Lanjutan) 


\section{Evaluasi Risiko}

Pada proses ini dilakukan pemilihan risk agent prioritas dengan memiliki nilai $\mathrm{ARPj}$ terbesar akan menjadi input pada HOR 2 yaitu risk agent prioritas yang akan dilakukan mitigasi. Penentuan risk agent prioritas, peneliti menggunakan sistem pareto. Berikut ini daftar risk agent yang akan dimitigasi.

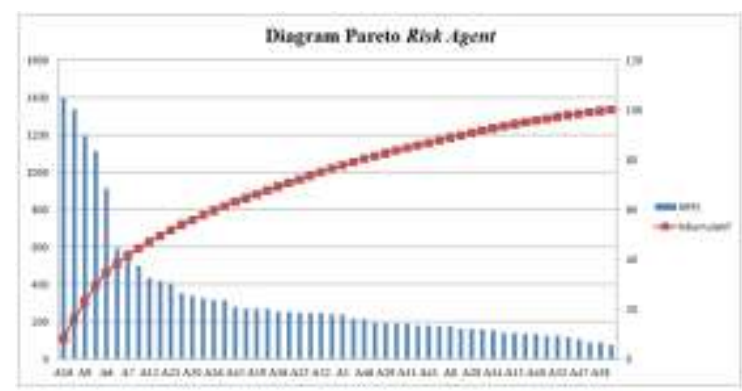

Gambar 4. Diagram Pareto Risk Agent

Biasanya, bagan pareto yang ideal adalah sepeti gambar 4.3 dibawah ini. Dimana bagan pareto yang ideal adalah bagan dimana sekitar $20 \%$ atribut memiliki bobot $80 \%$ (Grosfeld-Nir, Ronen, \& Kozlovsky, 2016) yang dimana dapat diartikan sebagaimana $80 \%$ kerugian diakibatkan oleh $20 \%$ risiko yang krusial. Dengan memfokuskan 20\% risiko yang krusial maka dampak risiko sebesar $80 \%$ dapat teratasi. Namun, kadang - kadang diagram pareto kurang informatif karena atribut yang berbeda yakni bagan pareto relatif seragam. Untuk mengidealkan bagan yang relatif seragam menggunakan entropy agar bagan tersebut memiliki control limits (Grosfeld-Nir, Ronen, \& Kozlovsky, 2016). Karena bagan pareto dalam penilitan ini termasuk bagan pareto yang ideal, maka peneliti akan mengambil 20\% risiko yang krusial sebagai berikut ini.

Tabel 7. Risk Agent Yang Akan Dimitigasi

\begin{tabular}{|c|l|c|c|}
\hline Code & Risk Agent & ARPj & $\mathrm{Pj}$ \\
\hline A16 & Kerusakan alat & 1397,5 & 1 \\
\hline A4 & $\begin{array}{l}\text { Keterlambatan } \\
\text { kedatangan } \\
\text { bahan baku }\end{array}$ & 1337,1 & 2 \\
\hline
\end{tabular}

\section{House of Risk Fase 2}

Setelah diketahui risk agent prioritas yang akan dimitigasi maka pada tahap ini akan dilkaukan perancangan strategi mitigasi (PAk). Pada penentuan aksi mitigasi ini dilakukan wawancara dengan pihak expert yang telah ditentukan oleh perusahaan. Hasil wawancara tersebut dapat dilihat pada tabel 8 berikut ini.

Tabel 8. Aksi Mitigasi (PAk)

\begin{tabular}{|l|l|}
\hline Code & \multicolumn{1}{|c|}{ Keterangan } \\
\hline PA1 & $\begin{array}{l}\text { Meningkatkan prosedur perawatan } \\
\text { preventif. }\end{array}$ \\
\hline PA2 & $\begin{array}{l}\text { Meninjau kembali dan merubah sistem } \\
\text { pengoperasian mesin. }\end{array}$ \\
\hline PA3 & $\begin{array}{l}\text { Melakukan perawatan mesin secara } \\
\text { korektif. }\end{array}$ \\
\hline PA4 & Melakukan perawatan mesin berjalan. \\
\hline PA5 & $\begin{array}{l}\text { Melakukan perawatan mesin secara } \\
\text { prediktif. }\end{array}$ \\
\hline PA6 & $\begin{array}{l}\text { Memberikan pelatihan khusus pada } \\
\text { setiap operator mesin produksi. }\end{array}$ \\
\hline PA7 & $\begin{array}{l}\text { Memperhitungkan konsep Re Order } \\
\text { Point (ROP). }\end{array}$ \\
\hline PA8 & $\begin{array}{l}\text { Melakukan evaluasi penjadwalan untuk } \\
\text { pemesanan bahan baku. }\end{array}$ \\
\hline
\end{tabular}

Setelah melakukan identifikasi aksi mitigasi yang memungkinkan untuk mencegah adanya risiko, selanjutnya adalah menentukan korelasi antar masing - masing aksi mitigasi dan masing - masing risk agent. Pada penilaian ini dilakukan oleh salah satu pihak expert yang telah ditentukan oleh perusahaan.

Setelah menentukan korelasi antar masing - masing aksi mitigasi dan masing - masing risk agent. Selanjutnya menghitung total efektivitas dari tiap tindakan dengan menggunakan rumus sebagai berikut.

$$
\mathrm{TE}_{\mathrm{k}}=\sum_{\mathrm{j}} \mathrm{ARP}_{\mathrm{j}} \mathrm{E}_{\mathrm{jk}}
$$

Setelah menghitung total efektivitas (TEk) masing - masing aksi mitigasi, selanjutnya yakni memberi penilaian terhadap tingkat kesulitan melakukan aksi - aksi mitigasi (Dk) dengan cara penyebaran kuesioner kepada bagian expert yang telah ditentukan sebelumnya. Dimana nilai tingkat kesulitan memiliki skala $1-5$.

Langkah selanjutnya yakni menghitung rasio total efektivitas dengan tingkat kesulitan (ETDk) dengan menggunakan rumus sebagai berikut :

$$
\mathrm{ETD}_{1}=\frac{T E 1}{D 1}=\frac{12.557,5}{2}=6.278,75
$$


Lebih jelasnya dapat dilihat pada gambar House of Risk Fase 2 berikut ini.

\begin{tabular}{|c|c|c|c|c|c|c|c|c|c|c|}
\hline \multirow{2}{*}{\multicolumn{2}{|c|}{ To be Treated Risk Agent (Aj) }} & \multicolumn{8}{|c|}{ Preventive Action (PAk) } & \multirow[b]{2}{*}{ ARPj } \\
\hline & & PA1 & PA2 & PA3 & PA4 & PA5 & PA6 & PA7 & PA8 & \\
\hline Kerusakan alat & A16 & 9 & 9 & 9 & 9 & 9 & 9 & 0 & 0 & 1397,5 \\
\hline Keterlambatan kedatangan bahan baku & A4 & 0 & 0 & 0 & 0 & 0 & 0 & 9 & 9 & 1337,1 \\
\hline Kurangnya penilaian terhadap pemilihan supplier & A9 & 0 & 0 & 0 & 0 & 0 & 0 & 0 & 0 & 1193,4 \\
\hline Ketersediaan bahan baku kurang & $\mathrm{A} 2$ & 0 & 0 & 0 & 0 & 0 & 0 & 3 & 9 & 1113,9 \\
\hline Tidak ada tempat parkir untuk kapal muatan bahan baku & A6 & 0 & 0 & 0 & 0 & 0 & 0 & 3 & 0 & 913,3 \\
\hline Terjadi penyusutan bahan baku saat proses pengiriman & A14 & 0 & 0 & 0 & 0 & 0 & 0 & 0 & 0 & 590,7 \\
\hline Perubahan jadwal produksi pihak supplier & A7 & 0 & 0 & 0 & 0 & 0 & 0 & 1 & 1 & 567,9 \\
\hline Kurangnya koordinasi dengan pihak supplier & A13 & 0 & 0 & 0 & 0 & 0 & 0 & 1 & 1 & 499 \\
\hline Pihak supplier kurang teliti dalam pengecekan & A12 & 0 & 0 & 0 & 0 & 0 & 0 & 1 & 1 & 433,3 \\
\hline Human error & A 21 & 0 & 0 & 0 & 0 & 0 & 9 & 0 & 0 & 417,3 \\
\hline Total Effectiveness of Action $-\mathrm{k}$ & & $\begin{array}{c}12.557, \\
50 \\
\end{array}$ & $\begin{array}{c}12.557,5 \\
0 \\
\end{array}$ & $\begin{array}{c}12.557,5 \\
0 \\
\end{array}$ & $\begin{array}{c}12.557,5 \\
0 \\
\end{array}$ & $\begin{array}{c}12.557,5 \\
0 \\
\end{array}$ & $\begin{array}{c}16.333,2 \\
0 \\
\end{array}$ & $\begin{array}{c}20.708,2 \\
0 \\
\end{array}$ & $\begin{array}{c}24.651,7 \\
0 \\
\end{array}$ & \\
\hline Degree of Difficulty Performing Action $-\mathrm{k}$ & & 2 & 3 & 2 & 2 & 2 & 2 & 3 & 2 & \\
\hline Effectiveness to Difficulty Ratio & & $\begin{array}{c}6.278,7 \\
5 \\
\end{array}$ & $4.185,83$ & $6.278,75$ & $6.278,75$ & $6.278,75$ & $8.166,60$ & $6.902,73$ & $\begin{array}{c}12.325,8 \\
5 \\
\end{array}$ & \\
\hline Rank Priority & & 4 & 8 & 5 & 6 & 7 & 2 & 3 & 1 & \\
\hline
\end{tabular}

Gambar 5. House of Risk Fase 2 


\section{Evaluasi Aksi Mitigasi}

Tahap selanjutnya adalah evaluasi dengan mengelompokkan (Preventive Action) dengan menggunakan sistem diagram pareto. Pengelompokan tersebut bertujuan untuk mengetahui preventive action prioritas. Untuk pengelompokan Preventive Action dapat dilihat pada gambar 6 berikut ini.

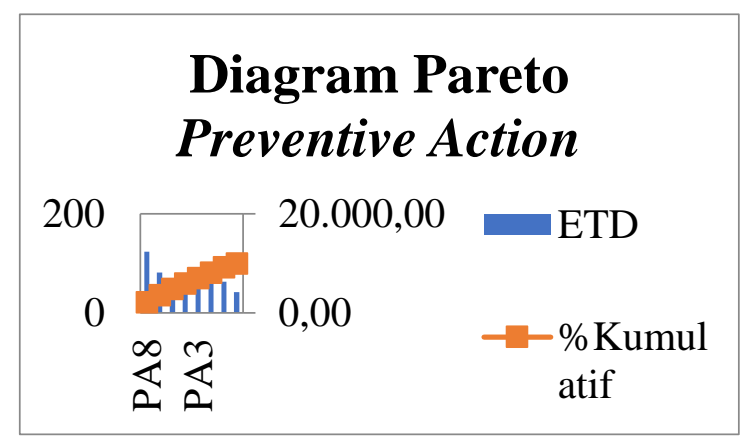

Gambar 6. Diagram Pareto Aksi Mitigasi

Seperti yang telah dijelaskan sebelumnya bahwasanya karena bagan pareto tersebut termasuk ideal, maka dari hasil diagram pareto diketahui Preventive Action yang menjadi prioritas akan dilakukan mitigasi yang dimana dapat dilihat pada tabel 9 berikut ini.

Tabel 9. Preventive Action Prioritas

\begin{tabular}{|c|c|c|c|}
\hline Code & $\begin{array}{c}\text { Preventive } \\
\text { Action }\end{array}$ & & Aksi Mitigasi \\
\hline PA8 & $\begin{array}{l}\text { Melakukan } \\
\text { evaluasi } \\
\text { penjadwalan } \\
\text { untuk } \\
\text { pemesanan } \\
\text { bahan baku }\end{array}$ & 3. & $\begin{array}{l}\text { Lobbying yang } \\
\text { lebih baik dengan } \\
\text { pihak supplier. } \\
\text { Koordinasi yang } \\
\text { lebih baik dengan } \\
\text { pihak ke tiga } \\
\text { mengenai parkir } \\
\text { kapal muatan } \\
\text { bahan baku. } \\
\text { Memperhitungkan } \\
\text { stock bahan baku } \\
\text { agar sesuai } \\
\text { dengan jumlah } \\
\text { produk yang akan } \\
\text { dihasilkan. } \\
\text { Saat pemesanan } \\
\text { ulang bahan baku } \\
\text { sebaiknya lebih } \\
\text { diperhitungkan } \\
\text { masalah waktu }\end{array}$ \\
\hline
\end{tabular}

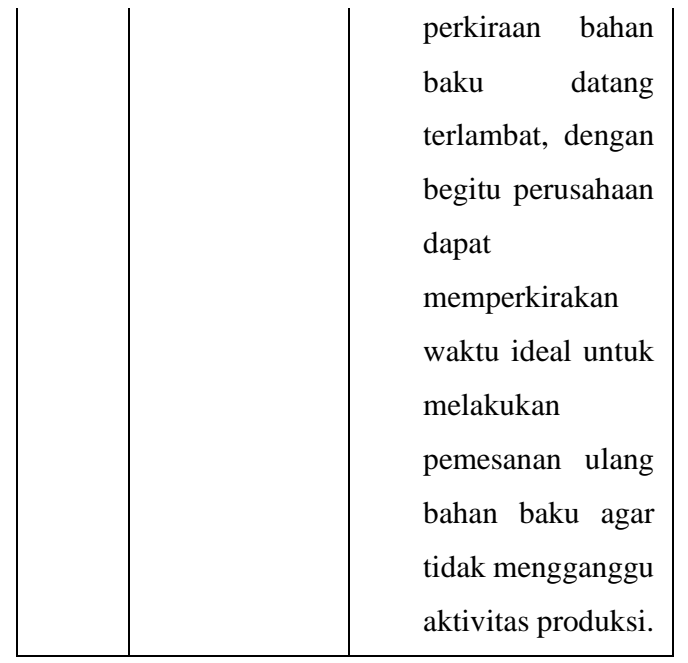

Semakin besar nilai ETD aksi mitigasi, maka semakin efektif dalam mereduksi atau memitigasi risk agent yang bersangkutan. Dengan nilai ETD juga dapat menentukan prioritas strategi mitigasi yang harus dilakukan oleh pihak perusahaan untuk memitigasi risk agenti yang mengakibatkan munculnya risk event.

\section{KESIMPULAN}

Adapun kesimpulan yang didapatkan antara lain :

1. Pada pengolahan HOR 1 digunakan untuk menentukan risk agent yang harus diberikan prioritas untuk tindakan pencegahan. Pada risk agent prioritas peneliti menggunakan sistem pareto untuk menentukan risk agent prioritas yang akan dimitigasi. Dari hasil tersebut terdapat 2 risk agent prioritas yang harus diberi tindakan/strategi mitigasi. 2 risk agent prioritas tersebut adalah kerusakan alat dan keterlambatan kedatangan bahan baku.

2. Hasil penentuan risk agent prioritas akan dimasukkan kedalam HOR 2 dimana akan diberikan perancangan/strategi mitigasi (preventive action). Aksi mitigasi tersebut dapat yakni : Meningkatkan prosedur perawatan preventif, Meninjau kembali dan merubah sistem pengoperasian mesin, Melakukan perawatan mesin secara korektif, Melakukan perawatan mesin berjalan, Melakukan perawatan mesin secara prediktif, Memberikan pelatihan khusus pada setiap operator mesin produksi, Memperhitungkan konsep $R e$ Order Point (ROP), Melakukan evaluasi penjadwalan untuk pemesanan bahan baku. 


\section{DATAR PUSTAKA}

Bahauddin, A., Minata, P.R., \& Arina, F. (2015). Analisis dan Strategi Penanganan Risiko Supply Chain Pada PT. Batik Banten Indonesia Menggunakan AHP dan FMECA. Performa, 14(1), 69-80.

Grosfeld-Nir, A., Ronen, B., \& Kozlovsky, N. (2007). The Pareto Managerial Principle : When Does It Apply?. International Journal of Production Research, 45, 10, 2317-2325, DOI: $10.1080 / 00207540600818203$.

Handayani, D.I. (2014). A Review : Potensi Risiko Pada Supply Chain Risk Management. Spektrum Industri, 14, 1108.

Kusumadewi, S. (2003). Artificial Intelligence (Teknik dan Aplikasinya). Jakarta : Graha Ilmu.

Pujawan, I.N., \& ER, M. (2010). Supply Chain Management. Surabaya : Guna Widya.

Puji, A.A. (2018). Analisis Mitigasi Risiko Rantai Pasok Dengan Integrasi Fuzzy Logic, House of risk, dan AHP. Tesis. Program Pascasarjana Fakultas Teknologi Industri Universitas Islam Indonesia. Yogyakarta.

Risqiyah, I.A., \& Santoso, I. (2017). Risiko Rantai Pasok Agroindustri Salak Menggunakan Fuzzy FMEA. Jurnal Manajemen \& Agribisnis, 14(1), 1-11.

Saepullah, A. (2017). Mitigasi Resiko Pada Proses Bisnis PT. ALIS JAYA CIPTATAMA Dengan Menggunakan Metode House of Risk. Skripsi. Program Studi Teknik Industri Universitas Islam Indonesia. Yogyakarta.

Sherlywati. (2016). Pengelolaan Risiko Rantai Pasok (Supply Chain Risk Management) Sebagai Keunggulan Bersaing Perusahaan. Prosiding MEBC 2016 Global Networking : Build Up Business Competiveness. Universitas Kristen Maranatha. 2-19.

Tampubolon, F., Bahauddin, A., \& Ferdinant, P.F. (2013). Pengelolaan Risiko Supply

Chain dengan Metode House of Risk. Jurnal Teknik Industri, 1(3), 222-226.

Trenggonowati, D.L \& Pertiwi, N.A. (2017).

Analisis Penyebab Risiko dan Mitigasi Risiko dengan Menggunakan Metode House Of Risk Pada Divisi Pengadaan PT. XYZ. Journal Industrial Servicess, 3(1a), 1-7.

Wang et al. (2009). Risk Evaluation in Failure Mode and Effects Analysis Using Fuzzy
Weighted Geometric Mean. Journal Expert System with Application, 36, 1195-1207. Winanto, E.A., \& Santoso, I. (2017). Integrasi Metode Fuzzy FMEA dan AHP Dalam Analisis dan Mitigasi Risiko Rantai Pasok Bawang Merah. Jurnal Teknologi Industri \& Hasil Pertanian, 22(1), 21-32. 